\title{
LYMPHATIC FILARIASIS IN NILPHAMARI DISTRICT: AN ENDEMIC AREA IN BANGLADESH
}

\author{
Hamida Khanum*, Iftekhar Hossain, Fahmida Sarkar and Rimi Farhana Zaman
}

Department of Zoology, University of Dhaka, Dhaka-1000, Bangladesh

\begin{abstract}
The present study was carried out in Nilphamari district, Filaria Hospital of Nilphamari district and from randomly selected three villages of Nilphamari Sadar and Paurasava, Sayedpur, Domar, Dimla, Joldhaka and Kishoreganj. The objectives of this study were to find out the status of lymphatic filariasis (LF) in Nilphamari district: An endemic area for LF in Bangladesh. The investigation was carried out among the inhabitants of the villages and the outdoor patients of Filaria Hospital in Nilphamari through a formatted questionnaire. The current status of this disease was $4.43 \%$ in Nilphamari Sadar and $3.25 \%$ in Paurasava, $4.10 \%$ in Sayedpur and similarly $4.82 \%$ in Domar, $5.86 \%$ in Dimla, $3.85 \%$ in Joldhaka and $4.70 \%$ in Kishoreganj. In Nilphamari district, it was found that male were more susceptible $(58.84 \%)$ than female (41.16\%). $76.22 \%$ male patients had hydrocoele and the disease showed its highest prevalence $(41.16 \%)$ in the age group of 41-60 years.
\end{abstract}

Key words: Lymphatic filariasis, prevalence, endemic area

\section{INTRODUCTION}

Mosquitoes are the only known vectors of lymphatic filariasis. Culex quinquefasciatus has been recognized as the vector of nocturnally periodic $W$. bancrofti. In African region, two freshwater breeding mosquitoes of Anopheles gambia complex, namely Anopheles arbinenses and Anopheles gambia are known as the filarial vectors. But in Libaria, Anopheles nile and Anopheles hancock have been incriminated as vector of filariasis. Anopheles danotities and Anopheles dirus have been found to be responsible for filariasis in western Pacific and in Southeast Asia, respectively. In Thailand, Aedes niveus and Aedes poecilus in Philippines have been incriminated as the vectors of Brugia malayi. Anopheles barbirostris has been reported as the vector of Brugia timori infection in Timor, Indonesia. Mansonia mosquitoes, Mansonia annulifera and Mansonia uniformis are vectors of Brugian filariasis in India (WHO 1998). Culex quinquefasciatus was found to be the only vector for bancroftian filariasis of nocturnal periodicity in Bangladesh (Khan and Wolfe 1972, Ahmed 1986).

It is estimated that 250 million people throughout the world are infected with Wuchereria bancrofti and Brugia malayi infections. W. bancrofti is endemic form in most of the tropical and subtropical regions of Asia, Africa, Latin

*Author for correspondence: <hamida_khanum@yahoo.com>

() 2018 Zoological Society of Bangladesh DOI: http://dx.doi.org/10.3329/bjz.v46i1.37622 
Sri Lanka, Maldives and Pacific islands, while B. malayi are seen in most of the countries of South-east Asia including India, Indonesia, Malaysia, Singapore, Central China, Thailand, Cambodia, Laos and South Korea and also in African sub-continent viz. Egypt, Gambia, Ghana, Nigeria, Guinea, Rhodesia and Nyasaland and Comoro island (census of Bangladesh - population and housing 2011, WHO 2014).

Filariasis is a severely debilitating and stigmatizing disease caused by the parasitic roundworm of Filarioidea type called Wuchereria bancrofti (CDCP 2010), classic causative agents of this disease in humans and is transmitted by mosquitoes. It is primarily a disease of the poor in tropical countries and is caused by three species of nematodes which are transmitted to humans by several genera of mosquitoes (Molyneux and Zagaria 2002). Culex sp. mosquitoes are the main vectors for transmission in Bangladesh. This disease is manifested by enlargement of the limbs, scrotum, and other extremities, is not the initial effect but the result of long-standing infection (Khanum et al. 2013). As worms block the lymph vessels, edema occurs, and in times the deposition of connective tissue cells and fibers contribute to lymphatic filariasis (LF).

The most spectacular symptom of LF is thickening of the skin and underlying tissues - which was the first disease discovered to be transmitted by mosquito bites (WHO 2013). LF is one the major leading causes of disability worldwide with the estimation of the global burden of the disease to be 5,644,000 Disability Adjusted Life Years (DALYs) (WHO 2004). This is the highest disease burden of any tropical disease except malaria. Lymphatic filariasis is one of the leading causes of physical deformation and disability in the world. Forty million people have visible ailments, 120 million are infected in 80 countries and one billion live in risk of infection (Ottenson 2000). In 2000 over 120 million people were infected, with about 40 million disfigured and incapacitated by the disease (WHO 2017).

The Filaria Hospital at Syedpur was established in 2001 and located in Syedpur, Nilphamari district; a part of highly endemic northern region. It has started functioning from 1 January, 2003. The hospital is the only specialized hospital of this kind in Bangladesh and globally. The Filaria Hospital has been providing morbidity control services to filariasis patients to reduce their sufferings. As a part of this activity the hospital has been conducting training to Government Health and Paramedical Health staff, NGOs, rural medical practitioners, volunteers etc. The hospital is able to provide support and train thousands of affected people every year. 
The objectives of the work were: (i) To determine the prevalence of filariasis in six unions of Nilphamari district (Nilphamari Sadar and Paurasava, Sayedpur, Domar, Dimla, Joldhaka and Kishoreganj) in relation to age and sex of the patients and (ii) to observe the sign and symptoms of filariasis among the patients.

\section{MATERIAL AND METHODS}

The study was conducted in Filaria Hospital of Savar, Filaria Hospital of Nilphamari, and other Thana Hospitals of Nilphamari and the rural areas namely Nilphamari Sadar and Paurasava, Sayedpur, Domar, Dimla, Joldhaka and Kishoreganj thana of Nilphamari district. These are epidemic prone areas in the Nilphamari district. The study design is a multistage sampling design with stages of selection at the following levels: district, Thana, road, hospitals and village. The study was done during the period of January, 2012 to December, 2012. The present study plan was prepared which was followed strictly and those are - preparation of a map of the study area, identification of the hospitals, meeting with Civil Surgeon and health officers of the study area, local leaders for cooperation and coordination, collection of relevant information of the study area and hospitals, and environment, etc.

In the present study, total 16731 families with 91945 members were investigated in six unions (Nilphamari Sadar and Paurasava, Sayedpur, Domar, Dimla, Joldhaka and Kishoreganj) from Nilphamari district. Data were collected through observation and questionnaire filling up. The schedule for data collection consisted of respondent's demographic socio-economic information, variables such as age, sex, educational qualification, economic condition, knowledge about disease, their attitude and practice towards the prevention and control of the disease. Finally tabulated data were analyzed and interpreted through the computer using the software, SPSS, MS Excel and MS Word.

\section{RESULTS AND DISCUSSION}

A total of 3841 persons (4.43\%) were found infected with filaria among the six unions. The highest percentage of infection was in Dimla (5.86\%) and lowest in Nilphamari Sadar (3.25\%) (Table 1). Wolf and Khan (1972) surveyed for night blood microfilaria in 17 districts (East Pakistan) and revealed that Dinajpur district, in the northwest corner of the province had highest prevalence of filariasis. Fourteen per cent of the people were examined in the institutions and villages throughout the district and found blood positive for Wuchereria bancrofti and hydrocele has been recognized as a common occurrence in the district for over a hundred years. A survey on filariasis in the entire Thakurgaon district 
was carried out by Bary et al. (1971) and revealed a microfilaria rate of $16.8 \%$ and a disease rate of $10.1 \%$. Survey carried out by NIPSOM in Thakurgaon district found that the microfilaria rate was $27.13 \%$ (73 positive out of 269 blood samples) (Ahmed 1986). In 2009, Ahmed also studied the endemic areas of northern part of Bangladesh which includes some unions of Nilphamari district.

According to Saha and Mohanta (2011), 33.39\% were male and $66.41 \%$ were female out of 2,32,005 populations of Kisorgonj and Sayedpur Thana under Nilphamari district. In the present study, $58.84 \%$ were male and $41.16 \%$ were female out of population (91945) of Nilphamari Sadar and Paurasava, Sayedpur, Domar, Dimla, Joldhaka and Kishoreganj from Nilphamari district (Table 2).

Table 1. Prevalence of filariasis in the people of the study area (Nilphamari Sadar and Paurasava, Sayedpur, Domar, Dimla, Joldhaka and Kishoreganj)

\begin{tabular}{lcccc}
\hline Union & $\begin{array}{c}\text { Total families } \\
\text { surveyed }\end{array}$ & $\begin{array}{c}\text { Total } \\
\text { members }\end{array}$ & $\begin{array}{c}\text { No. of } \\
\text { infected person }\end{array}$ & $\begin{array}{c}\text { Prevalence } \\
(\%)\end{array}$ \\
\hline Nilphamari Sadar & 6490 & 35662 & 1159 & 3.25 \\
Sayedpur & 803 & 4415 & 181 & 4.10 \\
Domar & 1268 & 6971 & 336 & 4.82 \\
Dimla & 2804 & 15410 & 903 & 5.86 \\
Joldhaka & 2652 & 14572 & 561 & 3.85 \\
Kishoregang & 2714 & 14915 & 701 & 4.70 \\
Total in Nilphamari & 16731 & 91945 & 3841 & 4.43 \\
\hline
\end{tabular}

Table 2. Prevalence of filarial patients according to sex in Nilphamari district

\begin{tabular}{lccc}
\hline Union & Male \% (number) & Female \% (number) & Total \% (number) \\
\hline Domar & $64(215)$ & $36(121)$ & $100(336)$ \\
Kishoregang & $56.78(398)$ & $43.22(303)$ & $100(701)$ \\
Nilphamari Sadar & $48.23(559)$ & $52.77(600)$ & $100(1159)$ \\
Sayedpur & $56.90(103)$ & $43.1(78)$ & $100(181)$ \\
Joldhaka & $79.68(447)$ & $20.32(114)$ & $100(561)$ \\
Dimla & $59.58(538)$ & $40.42(365)$ & $100(903)$ \\
Prevalence \% (number) in & $58.84(2260)$ & $41.16(1581)$ & $100(3841)$ \\
Nilphamari & & & \\
\hline
\end{tabular}

In the present investigation, highest percentage found in 41 - 60 age group (34.9) (Table 3) and lowest in 0 - 20 age group (17.78) (Table 3). According to Islam (2004), the highest percentage of infected persons was under the age group 31-40 years (30.69). Hawlader (2007) found the highest percentage (43.18) was from the age group 41 - 60 years and which is similar with the 
information by Saha and Mohanta (2011) stated that 6 - 15 years, showed the lowest rate (1.92) of infection.

In 2007, Hawlader also worked on lymphatic filariasis in Pirganj, Pirgacha, Taraganj and Gangachara unions of Rangpur district. In 2011, Saha and Mohanta studied Kisorgonj and Sayedpur thana under Nilphamari district. According to them, average $1.34 \%$ people were infected with filariasis out of $2,32,005$ populations in those area. The highest percentage of infected unions was Alam Biditor (1.35) under Kisorgonj thana and lowest infected union was Khatamadhupur (0.21) under Sayedpur thana.

Table 3. Prevalence of patients in different age groups

\begin{tabular}{lcccc}
\hline Union/Thana & \multicolumn{4}{c}{ Age group (years) } \\
\cline { 2 - 5 } & $0-20$ & $21-40$ & $41-60$ & $60+$ \\
\hline Domar & $20 \%(67)$ & $30 \%(101)$ & $34 \%(114)$ & $16 \%(54)$ \\
Kishoregang & $17 \%(119)$ & $32 \%(224)$ & $33 \%(232)$ & $18 \%(126)$ \\
Nilphamari Sadar & $7 \%(197)$ & $24 \%(278)$ & $39 \%(452)$ & $20 \%(232)$ \\
Sayedpur & $15 \%(27)$ & $28 \%(51)$ & $38 \%(69)$ & $19 \%(34)$ \\
Joldhaka & $18 \%(101)$ & $27 \%(151)$ & $36 \%(202)$ & $19 \%(107)$ \\
Dimla & $19 \%(172)$ & $36 \%(325)$ & $30 \%(271)$ & $15 \%(135)$ \\
Prevalence (\%) & $17.78 \%(683)$ & $29.41 \%(1130)$ & $34.9 \%(1340)$ & $17.9 \%(688)$ \\
\hline
\end{tabular}

Table 4. Prevalence of patients according to sign and symptoms in Nilphamari district

\begin{tabular}{lcccccc}
\hline Union & $\begin{array}{c}\text { Swelling of } \\
\text { legs \% } \\
\text { (Number) }\end{array}$ & $\begin{array}{c}\text { Swelling of } \\
\text { hands \% } \\
\text { (Number) }\end{array}$ & $\begin{array}{c}\text { Swelling of } \\
\text { breast \% } \\
\text { (Number) }\end{array}$ & $\begin{array}{c}\text { Hydrocele } \\
\% \\
\text { (Number) }\end{array}$ & $\begin{array}{c}\text { Others \% } \\
\text { (Number) }\end{array}$ & $\begin{array}{c}\text { Total \% } \\
\text { (Number) }\end{array}$ \\
\hline Domar & 56.55 & 3.57 & 0.3 & 36.31 & 3.27 & 100 \\
Kishorgonj & $(190)$ & $(12)$ & $(3)$ & $(122)$ & $(11)$ & $(336)$ \\
Nilphamari & 62.48 & 7.85 & 2.43 & 25.10 & 2.14 & 100 \\
Sadar & $(438)$ & $(55)$ & $(17)$ & $(176)$ & $(15)$ & $(701)$ \\
Sayedpur & $(98.08$ & 3.36 & 0 & 17.52 & 1.04 & 100 \\
& 50.83 & $(39)$ & $(0)$ & $(203)$ & $(12)$ & $(1159)$ \\
Joldhaka & $(92)$ & $(42)$ & 1.10 & 21 & 3.87 & 100 \\
Dimla & 19.61 & 0.71 & 5.53 & 73.44 & 0.71 & $(181)$ \\
& $(110)$ & $(4)$ & $(31)$ & $(412)$ & $(4)$ & $(561)$ \\
Prevalence & 58.80 & 3 & 2.77 & 34.77 & 0.66 & 100 \\
\% (Number) & $(531)$ & $(27)$ & $(25)$ & $(314)$ & $(6)$ & $(903)$ \\
\hline
\end{tabular}

According to Table 4, in Nilphamari district, among the total (3841) infected patients, highest 59\% (2266) had swelling of leg, 32.92\% (1265) had hydrocele, 
4.65\% (179) had swelling of hand, $2 \%$ (76) had swelling of breast and $1.43 \%$ (55) had others.

Current status of the outdoor patients in Filaria Hospital of Nilphamari: Sign and symptoms according to different age groups of patients in Filaria Hospital of Nilphamari (July, 2011 - June, 2012): In Filaria hospital of Nilphamari district, among the total patients (2709) lymphedema with lower limbs had $1.85 \%$ (50), hydrocele had $4.47 \%$ (121) and other symptoms had $0.70 \%$ (19) under the age group of 10-19 years. Total 7.02\% (190) were under the age 10-19 years (Table 5). Out of 2709 patients, lymphedema with lower limbs had $3.84 \%$ (104), hydrocele had $7.60 \%$ (206) and other symptoms had $0.60 \%$ (16) under the age group of 20-29 years. Total $12.04 \%$ (326) were under the age 20-29 years (Table $5)$. In the age group 30 - 39 years, out of 434 (16.03\%) patients, $4.47 \%$ (121) were with lymphedema in lower limbs, hydrocele had $10.60 \%(287)$ and other symptoms had 0.96\% (26) (Table 5).

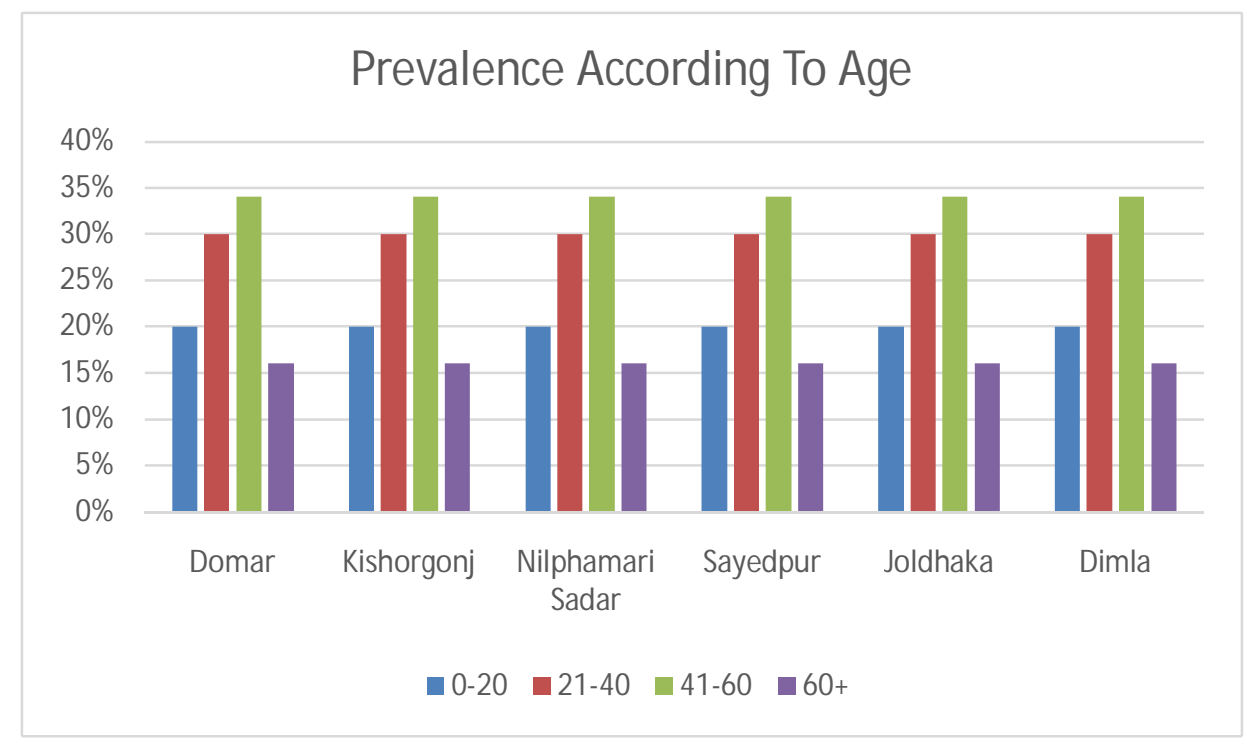

Fig. 1. Prevalence of filarial patients according to age in Nilphamari district.

Under the age group of 30-39 years old, lymphedema with lower limbs had $6.64 \%$ (180), hydrocele had 14.73\% (399) and other symptoms had $0.66 \%$ (18). Total 22.03\% (597) were under the age 40-49 years (Table 10). Lymphedema with lower limbs had $8.45 \%$ (229), Hydrocele had $15.39 \%$ (417) and other symptoms had $0.22 \%$ (6) under the age group of 50-59 years. Total $24.06 \%$ (652) were under the age 50-59 years (Table 5).

Lymphedema with lower limbs had 3.76\% (102), hydrocele had 9.23\% (250) and no other symptoms found under the age group of 60-69 years. Total $12.99 \%$ 
(352) were under the age 60-69 years (Table 10). Lymphedema with lower limbs had 1.51\% (41), hydrocele had 4.32\% (117) and no other symptoms found under the age group of $70+$ years. Total $5.83 \%$ (6) were under the age $70+$ years (Table 5).

The highest prevalence of filariasis (24\%) was found under the age group of 50-59 years, second highest was $22.03 \%$ under the age group of $40-49$ years. Lowest were $5.83 \%$ and $7.02 \%$ in the age group of $70+$ and $10-19$ years orderly. In Nilphamari Filaria Hospital among the total outdoor patients (2709) lymphedema with lower limbs had 30.52\% (827), hydrocele had $66.34 \%$ (1797) and others had $3.14 \%$ (85) in total (Table 5).

Table 5. Sign and symptoms according to different age groups of patients in Filaria Hospital of Nilphamari

\begin{tabular}{llllll}
\hline $\begin{array}{l}\text { Name of } \\
\text { hospital }\end{array}$ & $\begin{array}{c}\text { Age groups } \\
\text { (years) }\end{array}$ & \multicolumn{3}{c}{ Sign and symptoms } & $\begin{array}{c}\text { Total \% } \\
\text { (number) }\end{array}$ \\
\cline { 3 - 5 } & & $\begin{array}{c}\text { Lymphedema } \\
\text { with lower limbs } \\
\% \text { (number) }\end{array}$ & $\begin{array}{c}\text { Hydrocele } \% \\
\text { (number) }\end{array}$ & $\begin{array}{c}\text { Others \% } \\
\text { (number) }\end{array}$ & \\
\hline $\begin{array}{l}\text { Filaria Hospital } \\
\text { of Nilphamari }\end{array}$ & $10-19$ & $1.85(50)$ & $4.47(121)$ & $0.70(19)$ & $7.02(190)$ \\
& $20-29$ & $3.84(104)$ & $7.60(206)$ & $0.60(16)$ & $12.04(326)$ \\
& $30-39$ & $4.47(121)$ & $10.60(287)$ & $0.96(26)$ & $16.03(434)$ \\
& $40-49$ & $6.64(180)$ & $14.73(399)$ & $0.66(18)$ & $22.03(597)$ \\
& $50-59$ & $8.45(229)$ & $15.39(417)$ & $0.22(6)$ & $24.06(652)$ \\
& $60-69$ & $3.76(102)$ & $9.23(250)$ & $0(0)$ & $12.99(352)$ \\
& $70+$ & $1.51(41)$ & $4.32(117)$ & $0(0)$ & $5.83(6)$ \\
& $\begin{array}{l}\text { Total \% } \\
\text { (number) }\end{array}$ & $30.52(827)$ & $66.34(1797)$ & $3.14(85)$ & $100(2709)$ \\
\hline
\end{tabular}

Table 6. Length of illness in different age groups

\begin{tabular}{|c|c|c|c|c|c|}
\hline \multirow{2}{*}{$\begin{array}{l}\text { Name of } \\
\text { hospital }\end{array}$} & \multirow[b]{2}{*}{$\begin{array}{l}\text { Length of } \\
\text { illness } \\
\text { (years) }\end{array}$} & \multicolumn{3}{|c|}{ Sign and symptoms } & \multirow{2}{*}{$\begin{array}{l}\text { Total \% } \\
\text { (number) }\end{array}$} \\
\hline & & $\begin{array}{l}\text { Lymphedema with } \\
\text { lower limbs \% } \\
\text { (number) }\end{array}$ & $\begin{array}{l}\text { Hydrocele \% } \\
\text { (number) }\end{array}$ & $\begin{array}{l}\text { Others \% } \\
\text { (number) }\end{array}$ & \\
\hline \multirow{8}{*}{$\begin{array}{l}\text { Filaria } \\
\text { Hospital of } \\
\text { Nilphamari }\end{array}$} & $0-4$ & $3(80)$ & $9.70(263)$ & $1.33(36)$ & 14 (379) \\
\hline & $5-9$ & $3(81)$ & $11.44(310)$ & $0.55(15)$ & 15 (406) \\
\hline & $10-14$ & $2.80(76)$ & $11.96(324)$ & $0.77(21)$ & $15.53(421)$ \\
\hline & $15-19$ & $2.62(71)$ & $11.11(301)$ & $0.52(14)$ & $14.25(386)$ \\
\hline & $20-24$ & $2.80(76)$ & $9.97(270)$ & $0.55(15)$ & $13.32(361)$ \\
\hline & $25-29$ & $1.44(39)$ & $6.38(173)$ & $0.14(4)$ & $7.96(216)$ \\
\hline & $30+$ & 3.87 (105) & $15.65(424)$ & $0.41(11)$ & $19.93(540)$ \\
\hline & $\begin{array}{l}\text { Total \% } \\
\text { (number) }\end{array}$ & $19.5(528)$ & 76.22 (2065) & 4.28 (116) & 100 (2709) \\
\hline
\end{tabular}


Table 7. Prevalence of patients in Filaria Hospital of Nilphamari during the period of July, 2011 to June, 2012

\begin{tabular}{lllll}
\hline Year & Month & Male \% (number) & Female \% (number) & Total \% (number) \\
\hline 2011 & July & $6.83(185)$ & $3.65(99)$ & $10.48(283)$ \\
& August & $5.1(138)$ & $2.73(74)$ & $7.83(212)$ \\
& September & $4.68(127)$ & $2.52(68)$ & $7.21(195)$ \\
& October & $4.21(114)$ & $2.10(57)$ & $6.31(171)$ \\
& November & $4.43(120)$ & $2.21(60)$ & $6.64(180)$ \\
& December & $4.72(128)$ & $2.36(64)$ & $7.08(192)$ \\
& January & $4.95(134)$ & $2.47(67)$ & $7.42(201)$ \\
& February & $5.5(149)$ & $2.77(75)$ & $8.27(224)$ \\
& March & $5.80(157)$ & $2.91(79)$ & $8.71(236)$ \\
& April & $6.09(165)$ & $3.06(84)$ & $9.15(249)$ \\
Total \% (number) & May & $6.57(178)$ & $3.33(90)$ & $9.90(268)$ \\
\hline
\end{tabular}

Length of illness of the patients in Filaria Hospital of Nilphamari (July, 2011June, 2012): In Filaria Hospital of Nilphamari, among the total outdoor patients (2709) the highest 19.93\% (540) had been suffering for above 30+ years, $15.53 \%$ (421) had been suffering for 10-14 years, 15\% (406) had been suffering for 5-9 years, $14.25 \%$ (386) had been suffering for 15-19 years, $14 \%$ (379) had been suffering for 0-4 years, $13.32 \%$ (361) had been suffering for 20-24 years and the lowest 7.96\% (216) had been suffering for 25-29 years (Table 6). During the study period the highest prevalence among the outdoor patients was found in month of July, 2012 (11\%) and lowest in month of October, 2011 (6.31\%) (Table 7).

\section{CONCLUSION}

Lymphatic filariasis is one of the most disfiguring diseases and a major cause of clinical morbidity. It was found that this disease showed its highest prevalence in the age of 41-60 groups and 45\% patients were illiterate. So, illiteracy is one of the important social risk factors of this disease. The socioeconomic factors like poverty, illiteracy etc. are vital reason of the disease. So it can be revealed that the endemicity of filariasis is due to the environmental conditions and the climatic factor such as temperature, rainfall, humidity etc. were suitable for the parasite's existence of the study areas were very much suitable for breeding activities of the vector of filariasis, beside this negligence of the government is another national problem for the disease filariasis. 
Government should take proper step, such as increase awareness, distribute leaflet having the information about filariasis and its control and prevention, increase the rate of education, appoint the sufficient health workers to those area to ensure the proper health management, broadcast how filariasis may be prevented, cured or control on TV etc. Only one arrow is easy to bend off, but ten bundle arrows are much stronger. So everybody should come forward to control this national problem.

\section{LITERATURE CITED}

AHMED, H. 2009. Study on prevalence and epidemiological aspects of lymphatic filariasis: in endemic areas of northern part of Bangladesh. pp. 42-65.

AHMED, T. 1986. Filariasis in Thakurgaon. Bangladesh med. Res. Council bull. 12:83-94.

BARY, C., AHMED, A. and KHAN, A. Q. 1971. Endemic filariasis in Thakurgaon, East Pakistan. Am. J. Trop. Med. Hyg. 19: 181-189.

CENSUS OF BANGLADESH - POPULATION AND HOUSING. 2011. Bangladesh Bureau of Statistics Statistics and Informatics Division, Ministry of Planning.

CENTER FOR DISEASE CONTROL AND PREVENTION. 2010. Lymphatic filariasis.

HAWLADER, J. 2007. Study on lymphatic filariasis: the evaluation of knowledge, attitude and practices of inhabitants in Rangpur district. M.Sc. thesis, Department of Zoology, University of Dhaka, Bangladesh. p. 39-58.

ISLAM, C. 2004. Endemic filariasis In Thakurgaon district, M.Sc. Thesis, Department of Zoology, University Of Dhaka, Bangladesh. p. 49-57.

KHANUM, H., NATH, R., MUSA, S., ZAMAN, R.F. AND HOSSAIN, M.2013. Lymphatic filariasis in northern part of Bangladesh. Univ. J. Zool. Rajshahi Univ. 32: 59-65.

MOLYNEUX, D. H. and ZAGARIA, N. 2002. Lymphatic filariasis elimination: Progress in global programme development. Ann. Trop. Med. Parasitol. 96:15-40.

OTTENSON, E.A. 2000. The global programme to eliminate lymphatic filariasis. Tropical Medicine \& International Health 5(9): 591-94.

SAHA, A. K. and MOHANTA, M. K. 2011. Bancroftian Elephantiasis in Nilphamari, Bangladesh. Mymensingh Med. J. 20(1): 40-44.

WOLF, M. S. and KHAN, M. A. 1972. Filariasis in East Pakistan. Trans. R. Soc. Trop. Med. Hyg. 65: 63-69.

WORLD HEALTH ORGANIZATION. 2002. Lymphatic filariasis: The disease and its control. Technical Report 71: 21-323.

WORLD HEALTH ORGANIZATION. 2004. Lymphatic filariasis: progress of disability prevention activities. Weekly Epidemiological Record 79: 417-24.

WORLD HEALTH ORGANIZATION. 2013. Lymphatic filariasis. Health Topics $A$ to Z. WORLD HEALTH ORGANIZATION. 2017. Lymphatic filariasis: updated fact sheet. 